\title{
Revolutionary Metaphysics
}

JACK FOSTER

'A revolution is only communist if it changes all social relationships into communist relationships'. ${ }^{1}$ So reads the central pillar of communisation theory, an obscure school of 'ultra-left' thought dedicated largely to theorising what communist revolution is and how it could come about. As the communisation collective Endnotes writes, 'The history of capitalist society is the history of the reproduction of the capitalist class relation', which is to say, 'the reproduction of capital as capital' and of 'the working class as the working class'. ${ }^{2}$ The history of communist/socialist struggle has so far failed to prevent the reproduction of this relation, in large part, according to communisation theorists, because of the erroneous emphasis placed upon the self-realisation of the working class as the means of fomenting and achieving revolution. If capitalism is driven by the reproduction of capitalist class relations, communisation theorists contend, revolution oriented towards and reliant upon the selfrealisation of the working class can succeed neither in being communist nor in bringing about communism, as such a struggle can only end up reproducing capitalist

1 Gilles Dauvé, 'Communisation,' troploin, 2011, http://troploin. $\mathrm{fr} /$ node $/ 24$

2 Endnotes, 'Crisis in the Class Relation,' Endnotes 2 (2010). Available at https://endnotes.org.uk/issues/2/en/endnotes-crisis-inthe-class-relation 
social relations. Rather than communism being brought about through the victory of one class over another, then, communism can only come about through the disappearance of all social classes: communism must be oriented towards the self-abolition of the working class. ${ }^{3}$

It is therefore not so much the opposition between classes-between capitalists and workers - that is of concern for communist struggle as it is the opposition within the working class itself. Such a reading is shared by other Marxist thinkers. As Fredric Jameson suggests, for instance, historically this opposition has played out as a struggle between the 'pure element' of the working class-its supposed revolutionary potential as a collective actor-and its 'positioned form' - its capture in the capitalist life-world and 'domestication' by labour parties and trade unions. ${ }^{4}$ But such a reading typically gives birth to a 'stagist' conception of communist struggle: the idea that 'full communism' will come about only after a number of intermediary or transitionary steps; first the capture of the state by the working class, then its withering away, as in Leninism, for example. Communisation theorists reject such a reading, emphasising that communism is not a destination, but a mode of struggle that dissolves capitalist class relations within the struggle itself. 5 For those working in the communisation tradition, the question of revolution is therefore addressed from this standpoint: 'that a struggle which is directly and uncompromisingly targeted at the abolition of capitalist value-relations is the only kind capable of bringing about

3 Leon de Mattis, 'What is Communisation?' Sic 1 (2011): 24; Friends of the Classless Society, 'On Communisation and its Theorists,' Endnotes (2016). Available at https://endnotes.org.uk/other_texts/en/friends-of-the-classless-society-oncommunisation-and-its-theorists

4 Fredric Jameson, 'Badiou and the French Tradition,' New Left Review 102 (2016): 106.

5 Benjamin Noys, 'The Fabric of Struggles,' in Communisation and its Discontents, ed. Benjamin Noys (New York: Minor Compositions, 2012), 9. 
communist victory'. ${ }^{6}$ Communism is not a result, it is a process; class relations are undone in the process of revolution, not afterwards.

The Invisible Committee is an anonymous collective of French anarchists who develop an insurrectionist variant of communisation theory and practice. Influenced by the Situationist International and its critique of everyday life, the Invisible Committee's two previous manifestos, The Coming Insurrection and To Our Friends, have many pages dedicated to discussing the place of immediate insurrection in communisation. ${ }^{7}$ The committee's most recent work, Now, supposedly comprising the 'phantom chapter' of To Our Friends, is no exception. The members of the committee affirm the calls they make in earlier texts for rioting, the destruction of capitalist infrastructure, the formation of communes, and immanent exodus from the metropolises of contemporary capitalism. However, in their latest contribution, they appear distressed by the lack of present revolutionary activity. 'All the reasons for making a revolution are there',

6 Alberto Toscano, 'Now and Never,' in Communisation and its Discontents, ed. Benjamin Noys (New York: Minor Compositions, 2012), 93. This position is rooted in the Marxist concept of the transition from the 'formal subsumption' of labour to its 'real subsumption'. To extract surplus value, capitalists must subordinate labour to their own ends, they must take hold of existing labour processes and subordinate them to the capital valorisation process. This describes the 'formal' subsumption of labour. However, the search for surplus value and the competition between capitalists that this engenders drives the process further. Over time, the subsumption of the labour process becomes 'real' inasmuch as capital reshapes labour in its own image, reproducing labour as capital and deepening the areas in which surplus value can be produced. For communisation theorists, the shift from the formal to the real subsumption of labour sees capital create a world after its own image. See Endnotes, 'The History of Subsumption,' Endnotes 2 (2010). Available at https://endnotes.org.uk/issues/2/en/ endnotes-the-history-of-subsumption

7 Some would dispute this identification of the Invisible Committee within the tradition of communisation as the analysis and approach of its members differs significantly from most other communisation theorists or collectives. However, the members of the Invisible Committee are clear on their reading of communism as an immanent-unfolding process of dissolving capitalist class relations. In this sense, they are within the broad parameters of communisation theory, albeit occupying an extreme, anarchistic wing of this tradition. In the interests of avoiding an unnecessary technical discussion of the various streams of communisation literature, then, such issues are placed to one side in this review. 
they argue-massive wealth inequality, the disintegration of parliamentary politics, financial and economic crises, impending ecological apocalypse. Why, then, has wide-scale revolutionary activity not yet materialised? The reader is not kept in suspense on this matter. In the book's opening page, the authors note that 'it's not reasons that make revolutions, it's bodies'. And the bodies, apparently, are 'in front of screens', permanently distracted from the train wreck of contemporary capitalism and therefore incapable of overthrowing it. ${ }^{8}$

The Invisible Committee achieved relative infamy among readers of obscure Left theory, largely because of the supposed implication of some of its members in the 'Tarnac Nine' controversy in France. In November 2008, armed police arrested 20 people in Rouen, Paris, and the sleepy village of Tarnac. The nine who were eventually charged (with the addition of a tenth person arrested separately from the November raids) were accused of sabotaging high-speed train routes in France, an act of domestic terrorism. Among them was Julien Coupat, who, because of his intellectual background and previous membership in the Tiqqun collective, was fingered by the French state as the lead author behind The Coming Insurrection. Among other things, Insurrection called for the sabotage of capitalism's 'logistical chokepoints' as a means of insurrectionary resistance, explicitly asking, at one point, how a TGV line could be 'rendered useless'. Whether or not Coupat is indeed a leading author behind the Invisible Committee's work, the drama of the Tarnac Nine incident ensured that Insurrection was widely circulated and read.

By all accounts, the Invisible Committee formed out of the Tiqqun group, a milieu that published two journal volumes in France in 1999 and 2001 bearing the same name. Since then, much of the material collected there has been turned into books, either published by Semiotext(e) or released free online. ${ }^{10}$ The Invisible Committee's work is in direct dialogue

8 The Invisible Committee, Now (Los Angeles: Semiotext(e), 2017), 7.

9 The Invisible Committee, The Coming Insurrection (Los Angeles: Semiotext(e), 2015), 112.

10 The free material can be found at https://bloom0101.org/ 
with these earlier texts and draws on many of the concepts developed therein. Of major interest for Tiqqun was the nature of subjectivity under contemporary capitalism. In particular, the group theorised the political anesthetisation of the subject effected by consumerism, labour, massmedia, and surveillance in contemporary capitalism, outlining its critique in Theory of Bloom. ${ }^{11}$ Drawing on an array of theoretical influences, from the Situationists to Foucault, its members argue that contemporary capitalism, through the incessant production of 'spectacle' that erodes the meaning of language and the wider symbolic world, and the development of forms of power that govern social life from above and below, has produced a new, totalising form of domination they call 'Empire'. ${ }^{12}$ Empire imposes and reproduces a particular 'tonality of being' that structures our collective existence and subjective experience. ${ }^{13}$

Tiqqun articulates this tonality in the figure of 'Bloom' (a term détourned from James Joyce's Ulysses). Bloom is the subject fully subsumed by the logics of capital and devoid of the political capacities that could threaten the reproduction of the capitalist system. Bloom is estranged both from itself and from the social fabric which produces it, and yearns ineffectually for some vital connection or experience to deliver it from this alienation. Bloom is the logical end-point of a capitalism that has created a 'world after its own image', in which capital's insistence on the measurement and quantification of everything has transformed humans into capital. In such a world, the members of the Invisible Committee write in Now, 'Everyone becomes an enterprise guided by a constant concern with self-valorization, by a vital imperative of self-promotion'; capitalism has engendered 'its own optimizing humanity'. ${ }^{14}$ The many bodies that are glued to their screens instead of fomenting revolution on the streets are

11 Tiqqun, Theory of Bloom (2012). Available at https://bloom0101. org/?parution=theory-of-bloom

12 The concept of Empire appears to be directly lifted from the work of Michael Hardt and Antonio Negri, although Tiqqun and the Invisible Committee neglect to acknowledge this debt, and indeed are highly critical of Negri's work.

13 Theory of Bloom, 15.

14 Now, 100 [emphasis in original]. 
all 'Bloomified'. For the Invisible Committee, then, in seeking to undo capitalism, it is not so much the economic and political structures of class oppression that must be dissolved in communist struggle, but the very anthropological form that it has produced.

The question the committee's members pose is, therefore, not one of an internal struggle within the collective subject of the working class, but of an internal struggle between the captured part of the self-the part that is invested in the reproduction of capitalism — and the revolutionary partthe part of the self that wants something beyond life under capitalism. As they claim in an earlier text, 'There's no new revolutionary subject whose emergence has eluded observers'. ${ }^{15}$ Rather, revolutionary subjects can now only be created in the process of insurrection itself. The line of descent from the earlier work of Tiqqun is clear. As the group wrote in This is Not a Program:

Historical conflict no longer opposes two massive molar heaps, two classes - the exploited and the exploiters, the dominant and the dominated, managers and workers - among which, in each individual case, one could differentiate. The front line no longer cuts through the middle of society; it now runs through the middle of each of us. ${ }^{16}$

What is required of the communist revolutionary process is nothing other than the reconstruction of the subject from the ruin of Bloom.

The originality of this approach is found in how the committee's members conceive of subjectivity and the consequences of this for their revolutionary praxis. Against the conception of the subject as an individual with a fixed essence or identity, or of there being an essential human nature, they conceptualise subjectivity as something that only comes-into-being through the activation of the ties that bind one to others and to the world. The subject cannot be defined by an identity or essence, as identity is neither singular nor stable. In Now, they argue that, in contravention of this basic fact of existence, capitalism seeks to fix identity so that people can be named

15 The Invisible Committee, To Our Friends (Los Angeles: Semiotext(e), 2015), 44.

16 Tiqqun, This is Not a Program (Los Angeles: Semiotext(e), 2011), 12. 
and counted. But 'what there is in life', they proclaim, 'are not individuals endowed with all kinds of properties which they can make use of or part with. What there is in life are attachments, assemblages, situated beings that move within a whole ensemble of ties'. ${ }^{17}$ Subjectivity is determined by the links and relations between people and things that unfold situationally. In this way, subjectivity is radically open: it is something that is constantly in the process of becoming.

This reading applies to collective subjects as well as individual subjects. For the Invisible Committee, any collective identity is purely fictitious and ultimately repressive, confining the 'irreducible human plurality' to a restrictive set of predicates (and desires) to which members must conform. ${ }^{18}$ Because of the supposed impossibility of any totalisation of human plurality, and consistent with its conception of subjectivity as radically open, the Invisible Committee resists any form of organisation that seeks to fix in place a collective subject or organisational form for the articulation of its program.

Equally foundational to the committee's account of the subject is the contention that the social world is cloven by unresolvable and uncontainable antagonisms. While more sober theorists of antagonism argue for the construction of institutional frameworks through which antagonism can be mediated and productively articulated, the members of the Invisible Committee contend that no such space can or should exist. For them, politics is not something that is in any way stable or formulaic, so there is no neutral space in which it can be conducted. Institutions of the state or civil society inevitably articulate the interests of some at the expense of others; they are antagonistic agents in themselves. Consequently, in Now, they argue for the dislocation of politics from any fixed location, expanding its potential emergence to anywhere.

From these propositions the committee's members put forth the most original contribution that Now makes to their existing body of work.

17 Now, 136 [emphasis in original].

18 Now, 64. 
As they write:

The traditional revolutionary program involved a reclaiming of the world, an expropriation of the expropriators, a violent appropriation of that which is ours, but which we have been deprived of. But here's the problem: capital has taken hold of every detail and every dimension of existence. ${ }^{19}$

In this total capture, what is left, they propose, is only a politics of destitution, of simultaneously exiting from and totally destroying the capitalist web-of-life.

For too long, they argue, revolutionary politics has fallen prey to the 'iron cage of counter-revolution', the winning of institutional power by revolutionary actors inevitably giving way to a recrudescence of repressive institutions of power. ${ }^{20}$ For this reason, a communist politics of destination will always fail. In its place, they advocate a destituent politics of process that focuses on destroying all fixed sites of power while simultaneously constructing a 'new plane of existence' through the act of living communism. As they write: 'The destituent gesture is thus desertion and attack, creating and wrecking, and all at once, in the same gesture. ${ }^{21}$ Here the committee's members articulate a core tenet of communisation theory-communism as process_-adding to it a dubious politics of transcendent, immanentsituational truth: 'It's not a question of fighting for communism. What matters is the communism that is lived in the fight itself. The true richness of an action lies within itself' ${ }^{22}$ Such a struggle is premised on a renunciation of one's desire for concrete solutions and a concomitant faith that the process of communisation will enable the coming-into-being of something else. ${ }^{23}$

In earlier texts from Tiqqun, exactly what is meant by communism has been somewhat hard to discern. In Tiqqun's polemic Call, communism

19 Now, 84.

20 Now, 76.

21 Now, 88 [emphasis in original].

22 Now, 80 [emphasis in original].

23 Now, 127. 
'is about the elaboration of our relationship to the world, to beings, to ourselves. It is about the elaboration of the play between different worlds, about the communication between them'; communism is something that is 'possible at every moment'. ${ }^{24}$ In Now, the authors articulate this idea more coherently, arguing that the communist question is one that has been badly formulated from the beginning. It is not about achieving a communist community, they argue, because, like the subject, a community is not an entity; community is 'an experience of continuity between beings and with the world'. ${ }^{25}$ Community is simply the experience of play between bodies that engenders something greater than the sum of its parts. In this way, every experience of community is the unique result of a situation; communism is nothing other than the practice of bringing community into existence.

A certain asceticism and pastoral romance is evidenced in the attempt to define communism and community in this way. Take the following passage, for example:

In love, in friendship, we have the experience of that continuity. In my calm presence, here, now, in this familiar town, in front of this old sequoia sempervirens whose branches are stirred in the wind, I experience that continuity. In this riot where we all stick to the plan we've decided on, where the chants of the comrades give us courage, where a street medic delivers aid and comfort to an unknown person with a head injury, I experience this continuity. In this print shop dominated by an antique Heidelberg 4 Color which a friend ministers to while I prepare the pages, another friend glues, and a third one trims, to put together this little samizdat that we've all conceived, in this fervour and enthusiasm, I experience that continuity. ${ }^{26}$

This passage also evidences a certain attachment to insurrectionist virtues

24 Tiqqun, Call (2004), $63 \& 73$ [emphasis in original]. Available at https:// bloom0101.org/?parution=call

25 Now, 130-131 [emphasis in original].

26 Now, 131-132. 
and the supposed vitality of 'doing battle'. The act of oppositional insurrection against capitalism is posed as the means through which one can achieve communism: 'In the riot there is a production and affirmation of friendships, a focused configuration of the world, clear possibilities of action, means close at hand'. In the riot, 'lively and irreversible bonds' are created; the riot is desirable as a site and a 'moment of truth'. ${ }^{27}$ The suggestion appears to be that it is by plunging bodies into political action and confrontation that a politics of truth can (briefly) appear. Such passages betray a desire for the excitement of transgression and physical confrontation. Equally problematically, their argument seems to suggest that the careful analysis and interpretation of data cannot produce truth as truth is only situationally evident. This seems a radically ambiguous position to take in a world already threatened by so-called 'post-truth' politics and extreme political violence. Moreover, if it is the situation that generates the 'truth' of communism for communist militants, could not the same rule apply for fascist militants engaged in the act of attacking their perceived enemy? Indeed, there is a current of militarism running through the Invisible Committee's desire for a vital, bodily politics, in which the real 'stuff of life' is realised in the experience of 'authentic' political action on the streets.

Nevertheless, there is value to this deconstructed conception of community, the emphasis on the constitutive nature of ties, and the radicalising effects that confrontational political events can have. Capitalism, in the Invisible Committee's reading, produces Bloom through its reduction of the situational capacity for community to emerge, its shepherding of bodies away from this possibility. The lesson the committee's members stress is that 'If communism has to do with the fact of organizing ourselves-collectively, materially, politically-this is insofar as it also means organizing ourselves singularly, existentially, and in terms of our sensibility'.$^{28}$ Communist struggle in this sense is as much about one's orientation to the world as it is about one's critique of capitalism.

27 Now, 14 [emphasis in original].

28 Now, 142-143 [emphasis in original]. 
We arrive, then, at the Invisible Committee's definition of communism: 'To live communism is not to work to ensure the existence of the entity we belong to, but to deploy and deepen an ensemble of ties, which sometimes means cutting certain ones'. ${ }^{29}$ Such an open conception of what communism is or could be engenders a sense that one can experience it, not as a far-off maybe, but as something tangible that is accessible in the here and now. This potentially has political value as a mobilising and emotively nourishing idea and experience. But such a definition also suggests jettisoning any concerns with collective organisation as such-the party, collective workers' associations, pressure groups, the idea of planning-and replacing these with the constant articulation of a corporeal politics across all facets of life. Aside from this being an exhausting-sounding proposition, why maintain such a crude distinction between the politics of the present and the politics of planning for the future? The Invisible Committee's rejection of programmatic struggle, of revolutionary planning, of the slow, boring, patient work of developing revolutionary infrastructure and sustaining communities is predicated on the claim that planning is nothing but a symptom of Bloom's capture in the web of capitalism. As its members write: 'A mind that thinks in terms of the future is incapable of acting in the present. It doesn't seek transformation; it avoids it..$^{30}$ Of course, organisation developed around any constitutional framework is antithetical to their concept of communist subjectivity as something requiring continuous free play and movement. But there is no reason why this logic of free play and openness could not be applied to the act of planning itself. Why not an organisational form that gives priority to maximising the capacities for free play and the coming-into-being of community? Why not an organisational form that takes the liquidation of fixed interests and terms of engagement as its means of development?

Likewise, their methods for achieving this desired state of permanent transitionary free play are vague. They offer only the imperative that one must pay attention to the development of situations, to court the art of

\footnotetext{
29 Now, 144 [emphasis in original].

30 Now, 17.
} 
living on a 'situational footing', as they argued in an earlier text. ${ }^{31}$ The vagueness of these ideas leaves the question of communist content wide open: if communism is simply the engendering of community through the activation of ties between people in the context of a 'situation', can this not be achieved in situations that are inherently anti-communist? Such is the problem with developing a theory of what constitutes 'authentic' political action. ${ }^{32}$ Moreover, a great deal of faith is placed in people's capacity for sustaining this praxis of the situation, for forming communes and living a destituent politics without recourse to the stability of entrenched organisations or institutions. It seems a dubious faith to hold when the capacity of most to 'delink' from capitalist society is largely non-existent, a faith that is perhaps the result of a certain conception of human nature sneaking back in through the window-people as naturally communistic and anarchistic.

More promising is the committee's use of anonymity as a strategy of resistance. Resistance to any clear and crystallised subjectivity and to any institutional articulation of a collective will is a means, the authors argue, of resisting persecution by the state. As they write in The Coming Insurrection, 'To be visible is to be exposed, that is to say above all, vulnerable'; becoming invisible, in contrast, creates an 'invulnerable position of attack'. ${ }^{33}$ As Sven Lütticken has noted, the development of anonymous collective personae such as the Invisible Committee enables the authors to develop a politics that resists the crystallisation of power while also giving some kind of form, and thus permanence, to the entity that sits in opposition to such capitalist (or fascist) collective personae as the corporation, the state, the nation, or the ethnic community. ${ }^{34}$ It is a destituted collective subject from which one can attack capitalism anonymously and, thus, as far as the Invisible Committee is concerned, sustainably. But whether many people would feel

31 To Our Friends, 145.

32 Mackenzie Wark, 'No Futurism', Public Seminar, 22 June 2015, http://www. publicseminar.org/2015/06/no-futurism/

33 The Coming Insurrection, 113.

34 Sven Lütticken, 'Personafication: Performing the Persona in Art and Activism,' New Left Review 96 (2015): 119. 
this offers sufficient support to compel them to delink from mainstream society and engage in dangerous insurrectionary actions that often carry lengthy prison terms seems dubious. It appears more effective as an aesthetic strategy than anything else.

In Now, the authors' commitment to a politics of the situation goes hand in hand with a disavowal of the philosophical 'Idea of communism'. ${ }^{35}$ This also strikes a contradictory note. While they claim to be against the romantic theorisation of the communist struggle as a 'great historical struggle', the concept of the situation as a political site seems reliant on some temporal connection to the history of communism. A situation in which communism is evidenced is afforded power, that is, through the ability of the subjects who are involved in its construction to place it in the wider Manichean conflict between capitalism and communism. As Tiqqun writes in Call, the point is to conceive of every small act of communisation 'as a moment of the war against Empire..$^{36}$ In this sense, the 'moment', and, by extension, the how of the Invisible Committee's communisation, comes to rely in part on the historical edifice of the 'Idea of communism'. The historical arc of communist struggle and the Idea's enduring purchase complement the primal instinct and desire that the Invisible Committee assumes is being nourished by the act of sharing (human nature again making an appearance), and the heightened sensory experience that moments of subversion enable (a means of making corporeal and 'real' one's politics) as the emotive force driving communist militants forward.

The importance the committee's members attach to acts of communisation, therefore, appears to come at the price of a disavowal of much of the wider philosophy of communism on which they draw. While this is clearly a failure to think dialectically_why can't we have both the philosophy and the praxis?-it also stems from their rather dishonest theoretical positioning. In Now, they frequently disparage the practices of philosophy and sociology, advocating only for situated knowledge that develops in action. Yet despite their frequent denunciations of the academy,

35 Now, 135.

36 Call, 82 [emphasis in original]. 
the sheer volume of philosophical jargon they employ and the thinkers they are indebted to-Foucault, Agamben, Deleuze, Badiou, Negri, Debordthough seldom explicitly acknowledge, mean the reader will undoubtedly benefit from some background in these fields. In seeking to go beyond the Idea of communism and its relative confinement to academic philosophy and sociology, it might be more honest if the authors were to acknowledge their debt to the academy while also levelling their nonetheless-justified critique of it.

However, it is worth reading these authors on their own terms, an exercise which perhaps entails swallowing such contradictions or dishonesties whole and thinking of Now, like the group's earlier texts, and those of Tiqqun before them, as an experiment in practising communisation itself, of speaking directly to the reader in the hopes of engendering a 'situational truth'. The most effective elements of Now lie in the forceful writing with which the Invisible Committee delivers its critique and seeks to stir the reader to approach the world with fresh eyes. A muscular polemical ability and penchant for literary flair make for bracing reading in the book's best passages. The text is urgent in its delivery, drawing the reader into a headlong sprint towards the committee's proposed method of exit from contemporary capitalism. Underlying this, the authors remind us that communism, above all, should be about increasing individual and collective freedom; that a communism failing to deliver this, as much of its history has evidenced, is not worthy of the name. 